\title{
THE PROJECT / PROSPECTS OF "REDEEMING SIN?": SOME CORE INSIGHTS AND SEVERAL UNRESOLVED PROBLEMS
}

\author{
Ernst M Conradie \\ Department of Religion and Theology \\ University of the Western Cape
}

\begin{abstract}
This contribution offers an overview of a five-year project on Redeeming Sin that included a number of postgraduate projects registered at the University of the Western Cape, a series of international colloquiums hosted more or less annually, two monographs by Ernst Conradie (one forthcoming), and a number of articles. The notion of "redeeming sin" is ironic, as Christians typically speak of redemption from sin. Here it refers to attempts to retrieve the category of sin in the public sphere, for example in relation to ecological destruction, economic inequality and various forms of violence based on race, gender, language and culture. The polemic nature of the project is highlighted - to acknowledge but also to challenge a preoccupation with the theodicy problem (focused on the relationship between natural evil and social evil) in North Atlantic Christian theology.
\end{abstract}

Keywords: Anthropocene; Christian theology; climate change; food contestation; sin; social diagnostics

\section{Introduction}

In 2014 I registered a project entitled Redeeming Sin: Hamartiology, Ecology and Social Analysis at the University of the Western Cape (UWC). This was framed as a collaborative project involving staff members and postgraduate students at UWC. It became intertwined with three related projects, namely one on Food Contestation: Humanities and the Food System located at the DST-NRF Centre of Excellence in Food Security at UWC (led by Desiree Lewis and myself), ${ }^{1}$ ongoing work on Christian theology and climate change leading to the publication of the T\&T Clark handbook of Christian theology and climate change (2019), edited by Hilda Koster and myself, and a senior fellowship on the ethics of the Anthropocene entitled Whose Anthropocene What Diagnosis? that I held at the Institute for Environmental Studies at the Vrije Universiteit (VU) in Amsterdam. International collaboration on this project was facilitated especially through a series of colloquiums on Redeeming Sin? hosted in Stellenbosch in South Africa, and in San Antonio, Denver and San Diego in the United States between 2015 and 2019.

In this contribution I will highlight some of the core insights that I gained through this project and outline some of the many unresolved problems that were discussed and 
to some extent clarified. Although the insights gained are necessarily personal and reflected in the rather many publications mentioned below, such insights would not have been possible without many conversations with colleagues and students at UWC and the $\mathrm{VU}$ in Amsterdam, comments and questions from the audiences at numerous conference presentations and especially the in-depth critical explorations through the series of colloquiums mentioned above. I often had the sense that the discussions were probing the line of the watershed distinctions in Christian sin-talk. This is an attempt to capture some of these. I will give credit mainly to publications from such conversation partners as far as this is relevant, including work in progress.

\section{Sin-talk in the public sphere? The role of social diagnostics}

Christian sin-talk has been widely ridiculed in the public sphere. Nowadays it is no longer restricted to sexual indiscretions but also to sin-tax (smoking and drinking), sinfully delicious food, sugar tax, carbon sins or "sin bins" (e.g. in rugby). Can sin-talk be retrieved in the public sphere, for example to address environmental concerns, but also economic injustices related to poverty, unemployment, inequality and the many manifestations of violence - domestic violence, gangsterism, race discrimination, ${ }^{2}$ rape,${ }^{3}$ femicide, crime, corruption, ${ }^{4}$ hate speech, human trafficking, the mass migration of people, tariffs on trade, terrorism, civil war, etc? Clearly, the conciliar agenda of justice, peace and the integrity of creation requires the retrieval of sin-talk in the public sphere. But how should this be approached? A purely prophetic approach, as it were shouting from a safe religious distance, can only have a limited impact. ${ }^{5}$ If so, the only way forward is a multi-disciplinary approach where Christian theologians contribute to matters of public significance alongside other spheres of society (politics, industry, business, media, law and civil society) and alongside a range of other academic disciplines. ${ }^{6}$

This poses additional problems: While the role of faith-based organisations in civil society may still be acknowledged, especially in the African context, the legitimacy of Christian theology amongst other academic disciplines is highly contested. The question is: What can Christian theology contribute to public debates that other disciplines cannot? One may argue that the presence of theologians is in itself significant in order to ensure that some issues are addressed. There is sometimes a need to support what others have to say. Also, theologians may seek to speak alongside other activists on behalf of the voiceless (with the dangers that such representation entails). But at some point the distinct contribution of Christian theology needs to be clarified.

The assumption behind the project on Redeeming Sin? is that sin-talk may be regarded, at least from the outside, as a form of social diagnostics. ${ }^{7}$ Alongside medical

For one contribution within the context of the project on Redeeming Sin?, see Vorster (2016).

For feminist perspectives on sin-talk, see Baard (2019), Koster (2015a; 2015b), McDougall (2006; 2011; 2014).

See Baron (2018).

On the danger of issuing public statements without public engagement, see Conradie (2010a).

In Chapter 2 of Redeeming Sin? (2017c:29-60) I explore the question what such a multi-disciplinary conversation would require. See also Conradie (2015c) where I offer 12 theses on the place of Christian theology in multi-disciplinary conversations.

7 See especially Conradie (2017c; 2020a; also 2018d; 2018g). 
and psychological practitioners, political and economic analysts, and a range of other commentators, theologians may help to assess what has gone wrong with the world. With philosophers they may contribute to conceptual clarification in this regard and help to analyse and critique the underlying assumptions of their conversation partners. They would typically focus either on local pastoral experience or at the ultimate level on the deepest roots of the underlying problem.

My sense is that this proposal indeed helps to take the debate forward. The proof of the pudding still lies in its eating, but there is an intuitive recognition of the need for indepth diagnostics in the public sphere. Admittedly, an adequate diagnosis is only helpful if coupled with a prognosis and an appropriate remedy/therapy/policy. There may well be scepticism over any prescribed religious remedy (redemption from sin), but there should at least be some openness to a possible role of Christian sin-talk as a form of diagnostics.

From inside the Christian tradition sin-talk could be regarded as at least also a form of social diagnostics, although all problems are not only of a social nature. Whatever else sin may be (e.g. a broken relationship with God), it does have an impact in society. However, a re-description of social problems as "sin" should not be taken for granted. For example, what would it mean to describe climate change as a $\sin ?^{8} \mathrm{~A}$ deeper reservation may be that knowledge of sin is ultimately only possible through knowledge of salvation and indeed of the Saviour (see below). An acknowledgement of guilt before God emerges when one is confronted with the magnanimity of God's forgiveness. However, there may be many steps before such a recognition emerges and comes to fruition. It is theologically inappropriate to work only deductively from a position (e.g. the Nicene Creed or another confession) if that position was the result of a lengthy inductive process. Such prior steps need to be traced and retraced and can be debated in the public sphere. Another problem with social diagnostics is more serious. The search for an adequate diagnosis may not only be futile or become highly abstract and generalised. The possibility also exists that the diagnostic gaze itself is the problem since it may well presume a self-righteous appointment to assess what is wrong with the world, as it were from the outside. ${ }^{9}$ The famous comment by GK Chesterton comes to mind here. When asked by a newspaper to respond to the question as to what is wrong with the world, his alleged short answer was: "Dear Sir, I am. Yours, G. K. Chesterton.” But is his answer not somehow arrogant? Can one person be the cause of all the trouble?

\section{Three conceptual toolsets}

In recent contributions I offer three particular suggestions for how sin-talk can be retrieved in the public sphere, which can be briefly summarised as follows:

First, theologians can draw on an extended history of pastoral and prophetic experience that provides them with a conceptual toolbox loaded with the vocabulary for sin that may be required to name and analyse the underlying problem. At first, I identified five such concepts, namely sin as pride (anthropocentrism), greed (consumerism) ${ }^{10}$ sloth (failure, a lack of development), the violation of dignity (domination in the name of

See the reflections by Van den Brink (2018).

9 The warning of Slavoj Žižek (2011:358) is pertinent here: "Think about a religious fundamentalist who sees signs of sin and corruption everywhere in modern society - is the true evil not his suspicious gaze itself?"

10 See Conradie $(2009,2010$ c). 
differences) and the privation of the good (alienation). As the terminology in parentheses indicates, each of these Christian concepts have become secularised and open for public debate. Each is also relevant to address environmental concerns. If so, sin-talk may be helpful to explore the origins and the relationship between these concepts. ${ }^{11}$ In later contributions in conversation with Newton Cloete (a PhD candidate at UWC) I added the roles of sin as folly, pollution and corruption (which is related to the privation of the good). ${ }^{12}$

Second, the history of Christian theology yields a sensitivity for different ways in which the story of the emergence of evil and the subsequent conflict between good and evil can be told. There are not that many options available. In Christian debates these are distinguished as the Augustinian (good is original, corruption is total), the Pelagian (good is original, corruption is not total), the Manichaean (good and evil are co-original and in constant conflict) and the Irenaean (initially good and evil were undifferentiated) versions of the story. There may be many variations on these themes, but I maintain that these are the main options. It is remarkable that secular debates, at least in the West, follow these options as well. In Redeeming Sin? I outline these options in terms of the Manichaean-Darwinian-capitalist, the Augustinian-Marxist, the Pelagian-liberal and the Irenaean-Whiteheadian-Teilhardian trajectories. ${ }^{13}$ My sense is that some form of Manichaeism is the default option in contemporary debates ${ }^{14}$ albeit that there are two diverging trajectories, namely those who maintain either a tragic disposition (finitude, mortality, extinction will have the last word) or Promethean aspirations (the forces of good will ultimately trump the forces of evil). This is also applicable to discourse on the Anthropocene.

Third, in an unpublished manuscript on the Anthropocene I employ a different toolset derived from the theological critique of apartheid in South Africa in the 1970s and 1980s. There were different levels of criticism that did not exclude but complemented each other. Accordingly, apartheid could be regarded in terms of injustice (a violation of dignity), oppression (structural violence), ideology, quasi-soteriology, ${ }^{15}$ idolatry and also a form of heresy. Again, it is striking to see how secular discourse on sin adopts and adapts such categories to come to terms with what has gone wrong with the world - to the extent that humans have become a geological force of nature in the Anthropocene. One may observe that there is more common ground with other disciplines towards the one end of the spectrum (injustice), but theology can make a more distinctive contribution towards the other end of the spectrum (heresy). ${ }^{16}$

\section{Obstacles to a retrieval of sin in the public sphere}

In the introductory session of the first colloquium on Redeeming Sin? held at the

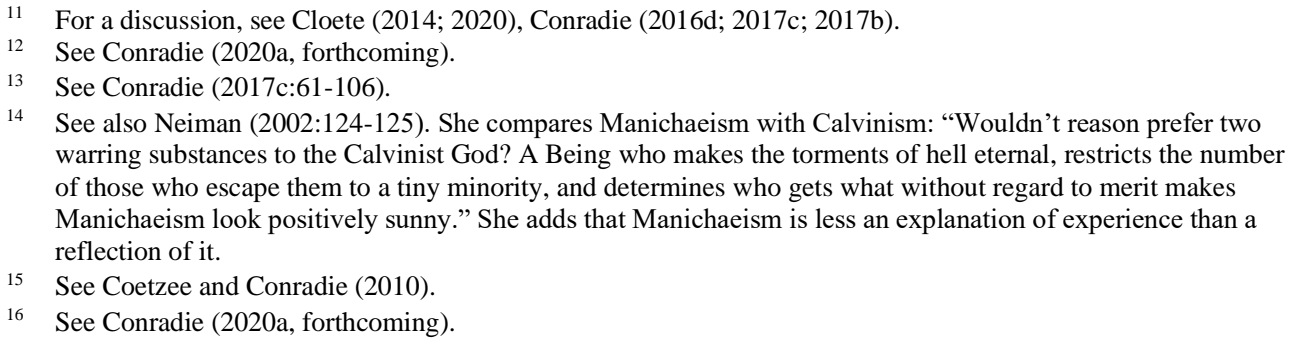


Stellenbosch Institute for Advanced Studies in 2015 I identified five obstacles that have to be addressed in order to retrieve the category of sin in the public sphere. At that stage these were merely mentioned intuitively. I discuss these five obstacles in more detail in Redeeming Sin?(2017) and have been grappling with them ever since. I will use these to structure the rest of this contribution, except the first one, namely the cultural ridicule around sin-talk in the public sphere. This certainly remains a reality but will not go away easily, even if all other problems can be resolved.

\section{What kind of category is sin?}

In Christian reflection on the nature of sin the same conclusion is reached again and again, namely that sin cannot be defined but can only be opposed. ${ }^{17}$ Any attempt to define sin may well underestimate the way in which sin morphs into different manifestations. If it can be captured in a single formula, it may also be possible to isolate, contain and surgically remove sin like a cancerous growth. Instead, sin is seen as elusive and hideous, ever re-emerging in new forms.

Nevertheless, in my view it is helpful to understand the category of sin. What kind of thing is $\sin$ ? Of course, it is not a thing but a category. In several contributions I list the following options which are clearly in tension with each other: ${ }^{18}$

- Sin describes individual acts of human wrongdoing: what individuals do to others, to themselves and to the surrounding nature by not doing what is right, not abiding by rules (anomie).

- Sin is not just a matter of doing, but also of thinking and saying. It is about dispositions, attitudes and attachments - which provide the breeding ground for wrongdoing. Sin affects the mind, the imagination, the sense of longing, desires, feelings, the will, the conscience and therefore also the senses, every part of the human body. ${ }^{19}$

- Sin also refers to what is left undone, a failure to accept responsibility, duties not fulfilled.

- Sin describes the character of a person rather than specific deeds that a person may do. Being a sinner is a more pervasive problem than committing acts of sin; it is much harder to stop committing habitual sins.

- Sin describes the quality of a (broken) relationship of trust and loyalty, not the dispositions or deeds of any one individual. Selfishness is a manifestation of a broken relationship. If so, one cannot sin on one's own. Sins in the plural are manifestations of broken relationships.

17 The same applies to attempts to understand the origins of evil. Dietrich Bonhoeffer (1997:120) understood this particularly well: "The question why there is evil is not a theological question, for it presupposes that it is possible to go back behind the existence that is laid upon us as sinners. If we could answer the question why, then we would not be sinners. We would blame something else. So the 'question why' can never be answered except by the statement 'that' which burdens humankind so completely. The theological question is not a question about the origin of evil but one about the actual overcoming of evil on the cross; it seeks the real forgiveness of guilt and the reconciliation of the fallen world."

18 See especially Conradie (2017c:120-130; 2018d; 2019b).

19 See the remarkable discussion by Herman Bavinck in his recently published Gereformeerde ethiek (2019:8993). 
- Such broken relationships are embedded in wider networks of families, clans, institutions and affiliations. Sin becomes manifest in what one party does to another but is indeed best described as a relationship going awry.

- Sin is best understood as structural violence; it describes systems of oppression such as patriarchy, slavery, colonialism, apartheid, castes, capitalism, ecological destruction - situations in which individuals and organisations alike are caught up.

- This may be true, but then the focus should be on the power of ideological distortions: sin is about classism, sexism, racism, elitism, homophobia, xenophobia, etc.

- Sin cannot be reduced to something moral but is primarily something religious. It is indeed about broken relationships but then a broken relationship with God, broken at least from our side.

- Sin is best understood as idolatry. ${ }^{20}$ If it is religious in nature, it is not merely about an individual's relationship with God but about unbelief, rebellion, idolatry, apostasy, putting one's trust in principalities and powers that cannot save us.

- Sin is about heresy, about radically distorting the Christian gospel to serve one's own interests.

What kind of thing is sin, then? The answer may well be that sin is not something that one can identify and describe but rather the privation of the good. This Augustinian position assumes the ontological priority of the good so that evil is a distortion of such good. Accordingly, in a sense sin does not exist, at least not on its own. This may well be contested on evolutionary grounds but rests on an affirmation of the goodness of creation and therefore the benevolence of the Creator.

Another way of reflecting on these notions of sin is in terms of the classic distinction between sin as guilt and as power. ${ }^{21}$ Some would focus on $\sin$ as guilt and then attend to things that individuals do. Others would focus on sin as power and then attend to how individuals are influenced by forces beyond their locus of control. We are caught up amidst evil forces that are more powerful than we can cope with and from which we cannot escape. A one-sided emphasis on either is dangerous. To focus on individual actions is to trivialise sin, to look for particular instantiations of sin as if there are other actions, attitudes, dispositions and thoughts that are not contaminated by sin. To focus on sin as power only is to portray individuals and groups as victims of forces beyond their control for which they therefore ultimately do not need to accept responsibility. This would undermine agency, also the agency of victims.

I think it is possible to combine an understanding of sin as power and as guilt in order to avoid such excesses. Perhaps one may start with sin as power (structural and cultural/ideological violence). Accordingly, sin may be understood as pervasive perversity. ${ }^{22}$ Sin is the mess that we find ourselves in.

One would then first need to add that this is a mess to which we (humans) and our predecessors have all contributed in one way or another, creating or worsening the mess.

See the innovative discussion by Stephen Fowl (2019) on the slow process through which idolatry emerges.

22 See the excellent discussion by Larry Rasmussen (2013:100). 
However, there is no need to argue that we have contributed equally. Consider the role of moral agents in positions of political and economic power but also moral patients (infants, the sick, the senile) on whose behalf others act. The victims of history are never completely innocent either and may well become the perpetrators of tomorrow. If we are all equally guilty, then we can no longer introduce gradations to establish who is truly guilty or not.

Second, this is a mess that causes suffering for all of us, including other animals and plants, albeit - again - not equally so. The suffering of victims may be obvious, but tyrants and torturers also suffer the consequences of oppression. However, it would be obscene to equate the suffering of the rapist and the rape victim. This is obviously relevant in the context of climate change where those who contribute next to nothing to carbon emissions will suffer, indeed are suffering, disproportionally under its impact.

Third, Augustinians (more than Pelagians) would add that this is a mess from which we cannot escape, at least not by ourselves. Our best efforts at moral renewal, reconstruction, transformation and social development remain flawed and often even exacerbate the problem. ${ }^{23}$ In short, sin describes the mess that we find ourselves in, to which we all contributed (but not equally so), under which we all suffer (again not equally so) and from which we cannot escape.

\section{Unresolved theological problems}

In Redeeming Sin? I also discuss a series of six unresolved and probably unresolvable theological problems around sin. ${ }^{24}$ Again these are simply listed here:

- Where does evil ultimately come from? The default (Augustinian) answer may be to define evil as the long-term impact of sin but that merely begs the question where sin then comes from (see below). This question cannot be resolved but must be addressed, if only to warn against inadequate responses to the question. Clearly, both monism (the view that God is the origin of everything including evil) and dualism (allowing for a power co-original with God) need to be avoided. As Robert Williams observes, "The classic doctrine is impaled on the first horn of the dilemma (original righteousness excludes sin), while modern theological reconstructions are confronted with the other (to acknowledge a flaw seems to equate finitude with sin)." 25

- If evil comes from sin (as suggested by an Augustinian critique of both monist and dualist approaches), where does sin come from? The question about the origin of evil should in my view not to be confused with the notion of original sin, that is primarily a comment on the pervasive consequences of sin that cannot be escaped and confront us collectively and individually. ${ }^{26}$ Again, this question has to be addressed, if only to

23 See the remarkable comment by Susan Neiman (2002:322): "The urge to unite is and ought stands behind every creative endeavor. Those who seek to unite them by force usually do more harm that they set out to prevent. Those who never seek to unite them do nothing at all."

25 Williams (1985:209).

26 The literature available on original sin in the light of evolutionary history has become quite extensive and, in my view, confusing, because the origins of sin and the pervasive impact of sin are conflated. On original sin in the context of the project on Redeeming Sin?, see Conradie (2016c), Houck (2020), Van den Brink (2015; 2017:207-260; 2018), Vorster (2015). Van den Brink identifies seven assumptions that constitute the "network" of original sin and captures these in the formula that original sin is "humans' universal, radical, 
respond to the many inadequate answers provided. Of particular concern is the suggestion by some theologians that sin is the more or less inevitable - if not strictly necessary - by-product of human freedom. Others, following the Gnostics, equate sin with anxiety over finitude. In both cases God ultimately has to accept responsibility for sin, for offering finite humans an ability to respond, knowing that they would face such anxiety.

- What, then, is the causal relation between sin and evil (the demonic) ${ }^{27}$ Is the problem of sin a subset of the problem of evil or vice versa? Does sin lead to evil or is evil the root cause of sin? Note that the question is not whether evil has causal efficacy. That is more or less obvious. What is less obvious is the interplay between sin, sickness and death. Clearly, from a theological point of view, sin is not always the cause of sickness, while, from an evolutionary point of view, death in God's good creation is not the result of sin. Nevertheless, sin does exacerbate natural suffering. Ongoing climate change is one thing, anthropogenic climate change is quite another.

- How serious is sin really? Does sin lead to a corruption but not the destruction of being human? What impact does it have on human nature? And on being the image of God? And on human freedom?

- What is the nature of sin? There is some consensus in theological literature that sin cannot be defined, it constantly appears in new forms and disguises. It is both fatal and fertile, leading to a progression of corruption, like a cancer killing by reproducing. To define sin may be to explain and to control it. This would underestimate the deviousness of sin and evil. However, this refusal to define sin does not resolve the problem since rival definitions are often offered in literature. Again, one needs to guard against inadequate responses. This debate remains far from resolved, as is indicated by framing the underlying question this way: How and where does sin enter into the tension between body and spirit, between flesh (the libido) and word (the tongue)? ${ }^{28}$ What about salvation? Does salvation enter from the side of the "flesh" (through genes, medicine, detoxification, vitamin supplements, muti, economic upliftment, technology, biotechnology, money, bread and wine), or via the "soul" (through language, culture and ideas)? The problem is that when theology falls prey to any form of dualism it tends to pay only lip-service to the biological rootedness of the human condition. This is not only theologically self-destructive but cannot

total, effective, acquired, hereditary and inculpating inclination towards sin" (2018:119). The hereditary (through sexual reproduction) and inculpating connotations are typically highly contested.

27 See Sakuba (2005), Conradie and Sakuba (2006).

28 I was surprised to see how assured Herman Bavinck is in responding to this question, namely in locating the origin of sin in the human consciousness. His answer is worth quoting at length: "We zien dus, dat de zonde zich ingang verschaft door het bewustzijn, werkt op die verbeeldingskracht, doet verlangen, zich uitstrekken naar de ideaal dat voorgespiegeld is en het eindelijk, door de zintuigen onder de invloed dier verbeelding waargenomen, doet grijpen. Voordat de daad dus volbracht is, heeft er in één enkel ogenblik een heel proces in de mens plaats gehad. De ganse mens is erdoor aangetast, in geest, ziel, lichaam, in verstand, gevoel en wil. ... Zo ontstaat nog elke zonde. Ons bewustzijn, door twijfel aangetast, concipieert een idee, onze verbeeldingskracht maakt er een ideal van, onze zintuigen geven dat ideaal in de zinlijke wereld gestalte, onze wil tracht het te grijpen. De éne zondige daad is dus een daad van die ganse mens, waar al zijn krachten, vermogens in meerder of minder mate aan deel hebben (2018:82). Bavinck adds that the reason why it is no longer possible to restore goodness after the first sin, is because the consciousness and therefore the will were infected, resulting in the state of sin. 

do scientific justice to the co-evolution of the human brain and symbolic language. ${ }^{29}$

- How is knowledge of sin possible? We may be able to realise that something is wrong in the world through general human experience. However, sin is more than knowledge of life's abnormalities and distortions. To locate the deepest roots of what went wrong in humanity's turning away from the triune God requires knowledge of the triune God. If so, the deepest question is not so much where evil comes from but where good comes from. How, then, is an understanding of the nature of sin correlated with an understanding of the nature of salvation? Is it true that sin can be recognised only from its inverse, i.e. from what it distorts, e.g. trust in God's love, the hope of shalom? How should the dialectic between law and gospel, or between sin and grace, be understood?

One rather surprising further comment suffices here, namely that none of these unresolved theological problems actually inhibit the retrieval of sin-talk in the public sphere. Distorted responses to these problems may do that, but recognising and admitting such problems is in fact a condition for retrieval in the public sphere. Perhaps some honesty in grappling with such issues - which are indeed of wider significance - is appropriate for Christian witness.

\section{The universality of sin}

In contemporary debates the universality of sin and therefore of guilt have become highly contested. One may observe that, despite resistance against inherited guilt, the notion of original sin (following Reinhold Niebuhr) retains some empirical credibility given its emphasis on the structural universality of sin as pervasive power. This prompted ongoing debates on how to reconcile the universality of sin with individual responsibility for sin - if universal sinfulness precedes individual sinful acts. ${ }^{30}$

The universality of sin remains attractive for several reasons. The Lutheran emphasis that all human beings have sinned before God, that we are all "beggars", that sin cannot be graded, is widely appreciated for its recognition of human equality. In most contexts guilt is mutually implicated, so that confession of sin may help to prevent or end a cycle of mutual accusations - where evil is always blamed on someone else or on some system of oppression (apartheid, colonialism) and where no one seems willing to accept responsibility for the destructive legacy of sin. Indeed, open confession is good for the soul and for the sake of community (Bonhoeffer again). The radical universality of sin also implies that evil cannot be attributed to only one group so that stigmatising and scapegoating others must be avoided. Evil is not merely something out there that has to be overcome or defeated or escaped from - since evil cannot be located somewhere outside ourselves. Moreover, moral exhortation and evangelical appeals for conversion remain insufficient to overcome an addiction to sin that is widespread, pervasive and delusional. The universality of sin is indeed a core assumption in much of evangelical theology, even though such a notion of sin often remains rather vague and even though structural dimensions of evil are often not recognised. At best it is a protocol against proposals that offer easy answers or quick fixes to eradicate evil.

29 See Conradie (2017c:155-160).

30 This section summarises the argument in Conradie (2017c:143-148, see also 2017d). 
By contrast, a sharp distinction between perpetrators and their victims has gained prevalence in several contemporary theological discourses. If sin has social consequences, the category of "being sinned against" is required in order to confront violence against women, slavery, torture, oppression, dictatorship and (environmental) destruction. There is nothing equal about the consequences of sin. If so, the language of sin can be used to disguise the suffering of victims and to obfuscate human evil. There seems to be a self-centredness in traditional discourse on sin in that the focus remains on the sinner rather than on the wounds of the victim, on the consequences of sin. Whereas confession may be the cry of the sinner, lament is the cry of the victim.

This debate clearly remains unresolved. On the basis of the suggestion above that sin may be understood as the "mess' in which we find ourselves, I suggest (following conversations with Miranda Pillay and other colleagues and students) the notion of the proportionality of guilt. ${ }^{31}$ Climate change, global economic inequalities and widespread violence suggest that we are in this mess together, even though not everyone contributed to it equally or suffer under it equally. ${ }^{32}$ Anton Rupert, at times the richest person in South Africa, rightly stated that if one's neighbours do not eat, one will not be able to sleep. He was a resident of Stellenbosch, one of the most unequal towns in the world, where this has implications for sanitation: If one's neighbours do not have access to adequate sanitation, this poses a disease risk for the whole population.

\section{The plausibility of the fall of humanity in evolutionary history}

In contemporary discussions on theology and evolutionary history there is widespread recognition that the biblical narrative of creation and the subsequent fall of humanity is not plausible. It is hard to read the early history of hominins as one where things went awry at a certain point (or period) in time. The argument has been reiterated so often that it is not worth repeating here. What is far less clear is what the theological implications of such a recognition may be. Should we drop the fall? ${ }^{33}$ Is it possible to "do away with a fall"? ${ }^{34}$ Is sin-talk at all possible without a notion of fall? Should one therefore hold onto a symbolic interpretation of the fall (an event happening time and again) rather than a historical interpretation (the fall as an event in human history)?

In my view this debate is partly mistaken or at least imprecise. To put this provocatively: there is no contemporary theologian who does not assume some notion of the fall. If one agrees with Cornelius Plantinga that things are "not the way it's supposed to be", 35 then one has to maintain that something went wrong somewhere sometime. If things could be better than they are, then this constitutes at least a minimal notion of a "fall" ${ }^{36}$ This need not imply a dramatic event but is based on prophetic moral

31 See the analysis in Conradie (2013a) and the further debates on restitution in Conradie (2018a; 2018b;2018g), also Nkosi (2016). On the basis of recognition that not everything can be given back in cases of injustice (the so-called "deficit"), I suggest a distinction between restitution (giving back what can be given back), compensation, reparation (creative strategies to address long-term injustices) and restoration (symbolic acts to restore broken relationships).

32 See also the distinction between the equality of sin and the inequality of guilt introduced by Reinhold Niebuhr (1941:222).

33 See Van den Brink (2011).

34 See Sollereder (2018), Southgate (2008:28-35).

35 See Plantinga (1995).

36 For an interesting discussion, see Smith (2017). 
discernment, a critique of the present more than a reconstruction of the past. And when the world is not as it ought to be, we have every reason to ask why. ${ }^{37}$

Consider the alternatives. There are only two that I can think of. The one alternative would assume satisfaction with present circumstances - which would invite a vehement critique of positions of power given domination in the name of gender, race, class, caste, language, culture, sexual orientation and species - you name it. Consider also Nietzsche's will to power by which he accepts the world as it is without wanting it to be different - which includes the will to live with all of its evils. ${ }^{38}$ At best, this is born from the fear that any desire for something better constitutes a betrayal of life itself. ${ }^{39}$ At worst, this serves as a legitimation of power. In the words of Adorno: "Only when that which is can be changed is that which is not everything." 40

The other alternative would assume that things may not be perfect, but this is the best that could be expected. This is a modification of Leibniz's best of all possible worlds argument, now framed in evolutionary history as an upward trajectory from brutish savages to civilised common humanity. ${ }^{41}$ While this view is quite common, it does not exclude a critique of the present in the sense that moral progress could have been further advanced than it is. This leaves room for a critique of various forms of violence, injustice and environmental destruction. If so, I would argue that this still assumes the need to reconstruct what went wrong and why human societies have not reached their full potential yet. This is surely a minimalist view of the "fall", but it illustrates the point that almost no contemporary scholar does not assume that something went wrong somewhere sometime, perhaps everywhere all the time.

My sense is that the real problem does not lie with the plausibility of the fall but with how the affirmation of the goodness of God's beloved creation can be reconciled with the reality of social evil. Since this affirmation is particular to the Jewish, Christian and Muslim traditions, such a problem would not necessarily emerge in other visions of the world, for example in a classic Greek sense of tragedy, Manichaeism, social Darwinism or contemporary discourse on socio-biology or evolutionary psychology. The affirmation of the goodness of God's beloved creation is in fact a deeply counter-intuitive confession of faith given the presence of pain, suffering, injustice, oppression and destruction in the world. ${ }^{42}$ The goodness of creation is often almost taken for granted but then only on the basis of a rather speculative reconstruction of how the world might have been before the impact of sin. This is also the way in which debates on the naturalistic fallacy are typically framed, namely that the gap between what is and what ought to be can be addressed through a reconstruction of the natural order so that the natural order and the moral order can be in harmony. But what if the natural order is itself deemed to be less than adequate?

I have argued elsewhere that such a reconstruction is not only speculative but completely misses the profound nature of the confession, namely that the world (or individual human beings) is declared to be good despite the obvious presence of evil. It

\footnotetext{
Neiman (2002:322).

See Neiman (2002:263).

See Neiman (2002:307).

Quoted in Neiman (2002:308, her translation).

This is the argument of Steven Pinker (2011).

On the counter-intuitive nature of the confession of God as Creator, see Conradie (2013c; 2014; 2015b).
} 
introduces a tension between what is and what ought to be, the world as we find it around us and the demand that it be different. This is at best possible through what I call the emergence of a liturgical vision, seeing the world through God's eyes, in the light of the Light of the world, as beloved by God despite its obvious fallenness. ${ }^{43}$ This is not an empirical claim but a counter-intuitive confession that requires much further explanation. One needs to tell the rest of the story to make sense of it.

This requires further theological discussion, but on this matter there is no consensus. It is at least clear that the story of good and evil is told in diverging ways, with farreaching implications for the moral of the story. In order to ensure a proper focus on the primacy of social evil I remain attracted to some form of the Augustinian version of the story, perhaps with some Irenaean revisions. ${ }^{44}$ I must admit though that this is hard to sustain. The Augustinian narrative assumes the (original) possibility of avoiding sin. The question is whether an affirmation of the notion of an original posse non peccare can be sustained given what we know of aggression, predation and natural disselection. ${ }^{45}$ Eating, one may say almost any kind of eating, provides a test case for the plausibility of an affirmation of posse non peccare. ${ }^{46} \mathrm{It}$ is not surprising that this has been heavily criticised while other alternatives have been explored. Such alternatives pose theological problems of their own, as I will indicate below. Likewise, the subsequent non posse non peccare (after the fall) also remains disputed given liberal (Pelagian) assumptions that we humans need to save ourselves from whatever evil we have caused and that we have it within us to do so, perhaps with a little help from God's side.

I presume that the point of divergence between these alternatives can be framed in many ways but the relationship between so-called natural evil and social evil comes close to the heart of the matter.

\section{The relationship between natural evil and social evil}

Framing the question with such terminology obscures two important issues. The first is that humans form part of nature and of the evolution of life so that a clear distinction between natural evil and social evil is not tenable. Humans form part of the ecosystems they are embedded in. In Christian categories: humans are God's creatures that do not somehow occupy a middle position between the Creator and other creatures.

The second is that the term natural evil remains awkward, at least if evil intentions (wickedness) ${ }^{47}$ or some form of intentionality are invoked. Social systems (such as apartheid) may be called evil since these are the collective outcome of institutionalised human decision making over longer periods of time. One may argue that other animals can be evil-minded, at least in terms of their temperament, and that there is some continuity between such "evil" and human evil. ${ }^{48}$ But the term natural evil is also used with reference to earthquakes (such as the one in Lisbon), natural disselection, viruses,

43

45

46

\footnotetext{
I explore this question in the context of the UWC project on Food Contestation. See Conradie (2015a; 2016b; 2016e; 2016f; 2018e; 2019a).

47 See the collection of essays on "wicked problems" to be published in Philosophia Reformata, including Conradie (2020b).

48 For a discussion, see Conradie (2017a), in conversation with amongst others Celia Deane-Drummond (2009).

See Conradie $(2014 ; 2015 b ; 2016 a)$.

This is the underlying tenor of my argument in Redeeming Sin? (Conradie 2017c).

I explore this question in Chapter 5 of Redeeming Sin? (Conradie 2017c:177-228).
} 

parasites, cellular degeneration, predation, death and extinction - where there is no suggestion of consciousness, freedom, intentions or decision making processes. If the term evil is to be used here, this should either be applied to an evil-minded divine Creator or to an inherent tendency in nature that comes to fruition amongst humans - in which case no distinction between natural evil and social evil is needed. One should remember what is at stake in making this distinction. Susan Neiman puts this starkly: "The distinction between natural and moral evil began as a debate about how much of the world's misery was God's fault, how much of it ours. Once God was overcome as a human projection, the distinction itself must be overturned." ${ }^{\prime 9}$ But abandoning God does not provide any solace: if evil forms part of nature itself, then it is hard to denounce crimes against nature. ${ }^{50}$

I suggest that it may be better to focus on forms of pain and suffering rather than on evil. One may say that suffering is not only a matter of pain but also the awareness of such pain, including past pain, and anxiety over possible future pain. One may of course find suffering amongst other animals with a degree of consciousness so that human suffering is one instantiation of animal suffering. "Natural suffering" could then be used to refer to forms of suffering in nature where humans are not involved. Given the global impact of human presence and the "end of nature", ${ }^{51}$ such suffering has become rather scarce, but the category of natural suffering would still apply to prehumen forms of suffering. This is the theodicy problem as posed in contemporary science and theology discourse. $^{52}$

While such distinctions may be helpful, one should not overlook the question about the underlying causes of such suffering. The word "evil" hints in this direction, namely that behind so much suffering must be some form of evil intent, sometimes referred to as metaphysical evil. In an earlier contribution I speak of "sources" of suffering. ${ }^{53}$ I identify six such sources, some found only amongst humans, namely self-induced suffering (e.g. lung cancer derived from smoking), vicarious suffering on behalf of others (a special case of self-induced suffering), suffering induced directly by another human (e.g. assault, rape, murder), structural violence (imperialism, colonialism, apartheid, patriarchy, heteronormativity, etc), suffering due to contingency (being in the right place at the wrong time) and finally suffering with purely or at least predominantly natural causes that are outside the locus of control of any moral agent (fragility, sickness, ageing, death, predation). The last category is often associated with a recognition of limits in power, space, time and knowledge. It is pastorally important to distinguish between such sources of suffering (e.g. in the case of poverty) although pastoral sensitivity also requires some hesitation to assign a particular source of suffering (as in the case of HIV infection).

The focus on (human) suffering is helpful to move away from attributing evil

\footnotetext{
See Neiman (2002:107).

See Neiman (2002:269).

The reference is to Bill McKibben (1989).

52 There is a sizable corpus of literature here, far too many to reference. I have been influenced particularly by many conversations with Christopher Southgate in this regard. In his sizable oeuvre, see especially Southgate (2008; 2018a; 2018b), and for my contributions in conversation with Southgate, Gijsbert van den Brink and others, see Conradie (2018b; 2018c; 2018e).

53 See Conradie $(2005 ; 2006 \mathrm{~b})$.
} 
intentions but does not resolve the underlying problem, namely how the possible sources of suffering are related to each other. My sense is that the first four of these are theologically easier to deal with, even while existentially hard to swallow. If one's suffering is the result of injustices for which one is partly responsible, then that could be addressed through the processes of reconciliation and restorative justice. ${ }^{54}$ This remains highly complex, but there are ample theological categories available to address such concerns. Natural suffering and the role of contingency are theologically harder to address because God's own complicity is implied. This is where the problem of relating human and other than human causes of suffering retains its sting

This problem can hardly be solved - existentially, philosophically or theologically. It cannot be avoided either. Indeed, in her superbly crafted book Evil in modern thought, Susan Neiman shows that this problem is core to understanding the whole history of modern philosophy ${ }^{55}$ Since the days of Job the best approach is not to seek final answers but to unmask the many inadequate answers for what they are. In Job's case he refused to accept that his suffering was the result of his own sins and could not relate it to the sins of others. He had to reckon with the possibility that his suffering was the result of a heavenly bet between God and Satan but refused to blame God for that either.

Let me mention two especially inadequate responses, retaining the categories of natural evil and social evil:

The first response suggests that social evil is the cause of natural evil. This presumes that what is incorrectly termed natural evil is in fact God's punishment for human sin, individually (in the form of sickness) or collectively (in the case of natural catastrophes). The widely presumed response to the Lisbon earthquake was that the earthquake was God's punishment for Lisbon's sins. If so, God is not the cause of moral evil, but God is the cause of natural evil! ${ }^{56}$ The inadequacy of this position has engaged modern intellectuals since then, including Leibniz, Kant and Hegel. According to Susan Neiman's analysis, Christianity maintains that human beings should take the blame for (all) suffering upon ourselves in order to give life in all its misery and grandeur meaning. Sin gives suffering an origin; redemption gives it a telos ${ }^{57}$ If some suffering cannot be traced back to sin, the myth of sin and redemption becomes implausible. If so, it seems that either a tragic vision or a Nietzschean will to power is more sensible.

The second inadequate response suggests that social evil is caused by natural evil. Expressed in theological terminology, sin is the almost necessary or at least inevitable result of human anxiety over finitude and the suffering that such finitude implies. ${ }^{58}$ But finitude is neither a form of punishment nor is it evidence of sin. It is not even a lack of something. Instead, the problem with finitude seems to be the vulnerability that it entails. As Susan Neiman puts it: "Either the world should have been made less vulnerable: we to moral corruption, or the world to being damaged by it." ${ }^{\text {"59 }}$ Michel Serres locates the

\footnotetext{
54 At UWC extensive work has been done on reconciliation since the early debates around the Belhar Confession. For more recent contributions, see Conradie (2013a; 2019c), Kobe (2015), Nkosi (2016), Solomons $(2018 ; 2019)$.

55 See Neiman (2002).

56 Neiman (2002:120). She adds: "After years of watching the Portuguese prefer the goods of this world to God's word, He determined to speak a little louder" (2002:243)!

57 Neiman (2002:216).

58 See Conradie as early as (2005a; 2005c; 2005d; 2007), also Kotze (2016).

59 See Neiman (2002:60)
} 
Project / Prospects of "Redeeming Sin?": Some Core Insights and Several Unresolved Problems 15 origin of evil more precisely in terms of the violence produced in the vicinity of boundaries by the exclusion of the other - the inverse of a sense of identity and therefore finitude. ${ }^{60}$

In other words, according to the second response, the blame for sin can be shifted to natural causes - which makes nature all the more threatening and senseless. ${ }^{61} \mathrm{We}$ humans are then the more or less innocent victims of forces beyond our control. Once suffering becomes manifest, sympathy for the victim is required. The underlying causes of such suffering can best be addressed through medicine and therapy at the individual level and through social contracts, policy making and appropriate forms of technology at the collective level. Economic growth and education are the keys to ensuring wellbeing for all. Where that fails, "development", 62 "safety nets" and "corrective services" may be required. This pathological and therapeutic model for addressing social evil is widespread in contemporary culture, not only in the West. It is not surprising that some commentators, including psychologists, respond with the question: "Whatever happened to sin?". ${ }^{3}$ The problem of guilt and complicity cannot be resolved through more therapy. ${ }^{64}$ Even where a deep sense of guilt is not invoked, moral (and legal) responsibility is required.

The lines demarcating these two responses become blurred when the category of contingency is introduced, ${ }^{65}$ typically invoking the problem of metaphysical evil. If this is the best of all possible worlds, at least in theory, this would seem to require an underlying sense of purpose or lawfulness: the laws of nature. If there is room for radical contingency, if God is playing dice, then this suggests some imperfection - and to accept imperfection is to accept a world that is not as it ought to be. To allow for contingency and the many forms of suffering that "accidents" bring, given the fragility of any form of life, is to acknowledge a source of suffering beyond law and purpose, beyond God or our locus of control. The logic of cause and effect is broken, but this yields an unbearable solution: suffering may be either a matter of deterministic fate (written in our genes if not in the stars) or more likely a matter of luck (the roll of the dice). This again suggests a tragic vision where the best one can do is to ride one's luck. ${ }^{66}$ Neither Hegelian nor Marxian attempts to embed contingency within a dialectic of necessity can resolve the

60 See Serres (2018:144). Serres argues that the course of evolution bifurcates with the emergence of selfconsciousness that enables the recognition of the evolutionary war of all against all. The human species emerges when it departs from this war of species. On this basis he poses a profound question: "How, consequently, can we free ourselves from evil without abandoning life itself since it entails death, entropy, filth, and crimes?" (147).

61 Again Susan Neiman (2002:236) grasps what is at stake: "The paradox is just this: the urge to naturalize evil arose from the desire to tame and control it. But the more it is tamed, the more the quality of evil disappears. This leaves us with the fear that evil wasn't captured but trivialized. The banal doesn't shatter the world but composes it."

62 See my critique of the concept of development (Conradie 2015b; 2016f).

63 The implied reference is to Menninger (1973).

64 See my earlier contributions on confessing guilt in the context of climate change (Conradie 2010b).

65 See the comment by Susan Neiman (2002:92): "Contingency blurs the lines between moral and natural evil the eighteenth century tried to draw, for it is both microscopic and all-pervasive. Chance can turn our best efforts into quixotic last stands. The will to be effectively moral is therefore the will to remove it."

66 Susan Neiman (2002:230), in conversation with Freud, observes that the Greek gods were invented to serve three functions: "to exorcise the terrors of nature, to reconcile us to the cruelty of fate and to compensate us for the suffering that civilization itself imposes". The laws of nature may help to address the first, the second remains unresolved, while the third, the need for civilisation, responds to the first two. 
underlying problem.

I conclude that natural evil (better: non-human sources of suffering) and social evil can neither be separated from each other (as the Kantian tradition maintained in response to the Lisbon earthquake), nor can these be fused to identify only one source of all suffering. The distinction between nature and morality, what is and what ought to be, can neither be abolished nor can it be maintained by insisting that evil is a moral category only ${ }^{67}$ The problem of relating these terms remains unresolved. ${ }^{68} \mathrm{We}$ (including agnostics and atheists) can neither relinquish the theodicy problem nor can we even begin to address it. Like children, we need to refuse to accept a world that makes no sense, even if, as adults, we know we cannot make sense of evil. ${ }^{69}$

\section{Social diagnostics and the primacy of social evil}

The notion of "social diagnostics" may easily fall into the traps associated with the second response described above given the way medical terminology is employed. However, the project on Redeeming Sin? (with the question mark) is best understood as a response to the one-sidedness of the second response. It assumes the theological need to emphasise the primacy of social evil. As I stated before, at least from an African perspective, "our primary problem is not vulnerability but rape, not service but slavery, not death but murder, not sickness but the spread of preventable diseases, not economic scarcity or even inequality but capitalism, not being ruled but Empire, not the evolution of species but the loss of biodiversity, not an always changing climate but anthropogenic climate change, not hunger due to inadequate food production but due to its skewed distribution and/or the over-supply of fast food with high sugar and high fat contents". ${ }^{70}$ Neither is it human anxiety but the arsenals built to alleviate such anxieties.

The assumption of the primacy of social evil is core to theological movements in the global South such as liberation theology, black theology, Dalit theology, African women's theology, indigenous theologies and non-Western forms of ecotheology. From this perspective, the apparent preoccupation with the problem of natural evil in science and religion discourse in Western contexts remains suspect, to say the least. Put briefly, the suspicion is that guilt for Western imperialism, slavery and genocide is attributed to

67 See Neiman $(2002: 257,267)$. She regards both Hegel and Nietzsche as representative of attempts to overcome the gap between nature and morality by abolishing either the one or the other. Strangely, Richard Dawkins' book The selfish gene may be regarded as an attempt to sustain the distinction: in the end he reaches the conclusion that we need to rebel against our genes (2006:200-201)!

68 There is ample literature on the emergence of sin in theological discussions of evolution. Often this is confused with the category of original sin. See my review of such literature in Redeeming sin? (2017) and the proposal developed in Chapter 5 that the category of "bifurcation" may be helpful to indicate that things can go wrong at various levels but that not all of these need to be categorised as sin. Things going wrong is not necessarily a moral or a religious concept; it may be used in business or sport without moral connotations. I recently reread Denis Edwards' discussion in The God of evolution (1999:60-70). He maintains a clear distinction between social evil and natural evil and does not make the latter the root cause of the former. Nature is damaged by human sin but not itself fallen (1999:67). I find his first thesis congenial to my own approach: "Humans are a fallible symbiosis of genes and culture, who experience drives and impulses from the genetic side of their inheritance as well as from the cultural side, and these drives and impulses can be disordered and mutually opposed. This experience is intrinsic to being an evolutionary human but it is not sin" (1999:65).

69 For Neiman (2002:325), to reject theodicy is to reject comprehension!

70 Conradie (2017c:110-111). 

natural evil! Put differently, a soteriological orientation ${ }^{71}$ (how God saves us from sin and evil) may be contrasted with an exploration of the theodicy problem (how we may "save" / defend God against various accusations), whether the focus is on social evil or natural evil (how could a loving Creator have given rise to a world governed by natural disselection and predation?). From the perspective of ecotheology it would not make sense to love creation while questioning the Creator for its inadequacies. ${ }^{72}$ Even if the same doctrinal themes are employed, soteriology and theodicy are two rather different ways of telling the story. ${ }^{73}$ Admittedly, the North Atlantic preoccupation with natural evil may be a response to the perceived threat of secularisation, namely that the existence of natural evil jeopardises the credibility of the Christian faith. ${ }^{74}$ If so, the question remains which interlocutors are privileged - the "cultured despisers of religion" or the victims of social evil.

I hasten to add that "primacy" requires further clarification. It is used here in a pastoral and prophetic sense - as priority public concerns on theological agendas. Such (political) primacy does not necessarily apply epistemologically (how does one begin to unravel the sources of suffering), ontologically (is evil co-original with good?) or chronologically (the slow evolution of morality and the emergence of moral visions). The order of being cannot be equated with the order of knowing. This is where the debate clearly remains unresolved. Nevertheless, it would be inappropriate to use this as an excuse for not addressing the problem of social evil with the urgency required. To do so, the project of Redeeming Sin (without the question mark) may in my view be helpful. It has gathered together some resources and core insights that may indeed help to retrieve the category of sin in the public sphere.

\section{BIBLIOGRAPHY}

Baard, RS. 2019. Sexism and sin-talk: Feminist conversations on the human condition. Westminster: John Knox Press.

Baron, Eugene. 2018. South African newspaper reports on corruption: A rethorical assessment. Unpublished $\mathrm{PhD}$ dissertation, University of the Western Cape.

Bavinck, Herman. 2019. Gereformeerde ethiek (bezorgd door Dirk van Keulen). Utrecht: KokBoekencentrum.

71 Especially three contemporary soteriological metaphors have been explored by UWC students under my supervision, namely liberation, reconciliation and reconstruction. See Conradie (2006a; 2010d; 2011), Brooks (2015), Solomons (2018).

72 See Neiman (2002:299).

73 See the intriguing proposal by Christopher Southgate regarding the need for a compound theodicy that combines various elements within a narrative scheme "that is consonant with the classic Christian confessions of creation, redemption and eschatological consummation" (2018a:305). He assumes the failure of fall-based arguments to account for natural sources of suffering. Redemption is therefore not from sin - since sin is inevitable in an evolutionary world - but from the disvalues (the many forms of suffering) embedded in the evolutionary process. Eschatological consummation is required to ensure a "new creation", "a dimension of existence in which there is no more suffering" (304). I would need to ask whether such salvation entails the redemption of the earth or redemption from the many flaws of God's otherwise quite good creation? Or is redemption aimed at making God's beloved creation fire-proof against sin (see Conradie 2013b; 2015b).

74 I am grateful to Frederick Simmons for helping me to recognise this. 
Bonhoeffer, D. 1997. Creation and fall: A theological exposition of Genesis 1-3 (ed. John W de Gruchy). Minneapolis: Fortress Press.

Brooks, K. 2015. "Deliver us from evil”: A critical analysis of soteriological discourse in African Pentecostalism. Unpublished MPhil thesis, University of the Western Cape.

Cloete, NM. 2020. What on earth is wrong with the world? Five Christian voices on hamartiology and ecology. PhD project (submitted November 2019), University of the Western Cape.

Cloete, NM. 2014. Hamartiology and ecology: A critical assessment of Dietrich Bonhoeffer's view on the nature of sin. Unpublished MTh thesis, University of the Western Cape.

Coetzee, MH and Conradie, EM. 2010. Apartheid as quasi-soteriology: The remaining lure and threat, Journal of Theology for Southern Africa 138:112-123.

Conradie, EM and Koster, HP (eds). 2019. T\&T Clark handbook on Christian theology and climate change. London et al: T\&T Clark.

Conradie, EM and Sakuba, XS. 2006. Sin and evil in African Christian theologies: A classification, Ned Geref Teologiese Tydskrif 47(1\&2):60-73.

Conradie, EM. 2005a. An ecological Christian anthropology: At home on earth? Aldershot: Ashgate.

Conradie, EM. 2005b. HIV/AIDS and human suffering: Where on earth is God?, Scriptura 89:406-432.

Conradie, EM. 2005c. On human finitude and eternal life, Scriptura 88:30-51.

Conradie, EM. 2005d. Towards an ecological reformulation of the Christian doctrine of sin, Journal of Theology for Southern Africa 122:4-22.

Conradie, EM. 2006a. Healing in soteriological perspective, Religion \& Theology: A Journal of Contemporary Religious Discourse 13(1):3-22.

Conradie, EM. 2006b. On responding to human suffering: A critical survey of theological contributions in conversation with the sciences. In Du Toit, CW (ed.), Can nature be evil and evil natural? A science-and-religion view on suffering and evil. Pretoria: Unisa, 165-188.

Conradie, EM. 2007. Human distinctiveness as a journey of discovery of (human) finitude, Journal of Theology for Southern Africa 128:4-17.

Conradie, EM. 2009. Christianity and a critique of consumerism: A survey of six points of entry. Wellington: Bible Media.

Conradie, EM. 2010a. Climate change and the common good: Some reflections from the South African context, International Journal of Public Theology 4:271-293.

Conradie, EM. 2010b. Confessing guilt in the context of climate change: Some South African perspectives, Scriptura 103:134-152.

Conradie, EM. 2010c. Globalisation, consumerism and the call for a status confessionis. In Boesak, AA and Hansen, L (eds), Globalisation Volume II: Global crisis, global challenge, global faith-An ongoing response to the Accra confession. Stellenbosch: SUN Press, 53-76.

Conradie, EM. 2010d. The salvation of the earth from anthropogenic destruction: In search of appropriate soteriological concepts in an age of ecological destruction, Worldviews: Global Religions, Culture, Ecology 14:2-3, 111-140. 
Conradie, EM. 2011. Missiology and soteriology: The power and limits of a multidimensional approach, Missionalia 39(1/2):83-98.

Conradie, EM (ed.). 2013a. Reconciliation as a guiding vision for South Africa? Stellenbosch: SUN Press.

Conradie, EM. 2013b. Saving the earth? The legacy of reformed views on "Recreation”. Berlin: LIT Verlag.

Conradie, EM. 2013c. The God of life: A counter-intuitive confession, The Ecumenical Review 65(1):3-16.

Conradie, EM. 2014. What on earth did God create? Overtures to an ecumenical theology of creation, The Ecumenical Review 66(4):433-453.

Conradie, EM. 2015a. Eat and/or be eaten: The evolutionary roots of violence?, Scriptura 114:1-22.

Conradie, EM. 2015b. The earth in God's economy: Creation, salvation and consummation in ecological perspective. Berlin: LIT Verlag.

Conradie, EM. 2015c. Twelve theses on the place of Christian theology in multidisciplinary conversations, Stellenbosch Theological Journal 1(1):375-386 (with responses by Wentzel van Huyssteen, Gys Loubser and Daniel Veldsman).

Conradie, EM. 2016a. An emerging horizon: Learning to see the world in a different light through the liturgy. In Buxton, $\mathrm{G}$ and Habel, $\mathrm{N}$ (eds), The nature of things: Rediscovering the spiritual in God's creation. Eugene: Pickwick, 41-57.

Conradie, EM. 2016b. Climate justice, food security ... and God: Some reflections from the perspective of ecotheology. In Werner, D and Jeglitzka, E (eds), Climate justice and food security: Theological education and Christian leadership development. Geneva: Globethics.net, 109-134.

Conradie, EM. 2016c. John Haught on original sin: A conversation, HTS Teologiese Studies/Theological Studies 72(4):1-10.

Conradie, EM. 2016d. Penultimate perspectives on the root causes of environmental destruction in Africa, Scriptura 115:1-19.

Conradie, EM. 2016e. What do we do when we eat? Part 1: An inconclusive inquiry, Scriptura 115:1-17.

Conradie, EM. 2016f. What do we do when we eat? Part 2: A theological inquiry, Scriptura 115:1-19.

Conradie, EM. 2016g. Why can't the term development just be dropped altogether? Some reflections on the concept of maturation as alternative to development discourse, HTS Teologiese Studies/Theological Studies 72(4):1-11.

Conradie, EM. 2017a. Do only humans sin? In conversation with Frans de Waal. In Fuller, M and Evers, D (eds), Are we special? Science and theology questioning human uniqueness. Heidelberg: Springer, 117-135.

Conradie, EM. 2017b. Laudato Si and the root causes of ecological destruction. In Warmback, A (ed.), A review article on Laudato Si, Journal of Theology for Southern Africa 157:138-145.

Conradie, EM. 2017c. Redeeming sin? Social diagnostics amid ecological destruction. Lanham: Lexington Books.

Conradie, EM. 2017d. The Gospel: Just for sinners or just for the sinned against? (with responses by Christine Hong, Brian Powers and Mindy McGarrah Sharp, and a 
rejoinder). @ this point: Theological Investigations in Church and Culture 12:2. Available online: http://www.atthispoint.net/.

Conradie, EM. 2018a. Om reg te stel: Oor regverdiging én geregtigheid. Wellington: Bybelmedia.

Conradie, EM. 2018b. On social evil and natural evil: In conversation with Christopher Southgate, Zygon: Journal of Religion and Science 53(3):752-765.

Conradie, EM. 2018c. The Christian faith and evolution: An evolving, unresolved debate, Verbum et Ecclesia 39(1):1-13.

Conradie, EM. 2018d. To cover the many sins of Galamsey Mining, Missionalia 46(1):109-130.

Conradie, EM. 2018e. To eat or be eaten? That's the question. In Baumann, Whitney and Hobgood, Laura (eds), The Bloomsbury handbook of religion and nature: The elements. London: Bloomsbury, 63-80.

Conradie, EM. 2018f. Ways of viewing an evolving world amidst ecological destruction, Scriptura 117:1-13.

Conradie, EM. 2018g. What diagnosis? Which remedy? Critical reflections on the diagnostic overview of South Africa's National Planning Commission, Scriptura 117:1-21.

Conradie, EM. 2019a. Could eating other creatures be a way of discovering their intrinsic value?, Journal of Theology for Southern Africa 164:26-39.

Conradie, EM. 2019b. The emergence of human sin. In Conradie, EM and Koster, HP (eds), T\&T Clark handbook on Christian theology and climate change. London et al: T\&T Clark, 384-394.

Conradie, EM. 2019c. The UWC reception of Gustaf Aulén's Christus Victor typology, Svensk Teologisk Kvartalskrift 95:79-92.

Conradie, EM. 2020a. What's wrong with the world? Secular discourse on sin in the Anthropocene. Manuscript submitted for publication with Lexington Books.

Conradie, EM. 2020b. Why, exactly, is climate change a wicked problem? Article submitted for publication in Philosophia Reformata.

Dawkins, R. 2006. The selfish gene. Oxford: Oxford University Press.

Deane-Drummond, CE. 2009. Christ and evolution: Wisdom and wonder. Minneapolis: Fortress Press.

Edwards, D. 1999. The God of evolution: A trinitarian theology. New York: Paulist Press.

Fowl, SL. 2019. Idolatry. Waco: Baylor University Press.

Houck, D. 2020 (forthcoming). Aquinas, original sin, and the challenge of evolution. Cambridge: Cambridge University Press.

Kobe, L. 2015. The relationship between remorse and offering forgiveness: Selected case studies from the South African Truth and Reconciliation Commission. MTh mini-thesis, University of the Western Cape.

Koster, HP. 2015a. Ecological evil, evolution, and the wisdom of God. In Daggers J and Kim, GJS (eds), Christian doctrines for global gender justice. New York: Palgrave Macmillan, 55-72.

Koster, HP. 2015b. Ecological evil, sin and redemption in the Anthropocene: An ecofeminist approach. Paper read at a colloquium on Redeeming Sin?, Stellenbosch, August 2015. 
Kotze, M. 2016. GM food and collective sin: A Christian theological ethical reflection, Scriptura 115:1-10.

Kotze, M. 2016. Fighting finitude?. Paper read at a colloquium on Redeeming Sin, San Antonio, November 2016.

McDougall JA. 2014. The bondage of the eye/I? A transnational feminist wager for reimagining the doctrine of sin. In Daggers J and Kim, GJS (eds), Reimagining with Christian doctrines: Responding to global gender injustices. New York: Palgrave Pivot, 105-125.

McDougall, JA. 2006. Sin-no more? A feminist re-visioning of a Christian theology of sin, Anglican Theological Review 88(2):215-235.

McDougall, JA. 2011. A trinitarian grammar of sin, Modern Theology 27(1):55-71.

McKibben, B. 1989. The end of nature. New York et al: Penguin.

Menninger, K. 1973. Whatever became of sin? New York: Hawthorn.

Neiman, S. 2002. Evil in modern thought: An alternative history of philosophy. Princeton and Oxford: Princeton University Press.

Niebuhr, R. 1941. The nature and destiny of man: A Christian interpretation Volume 1: Human nature. New York: Charles Scriber's Sons.

Nkosi, MS. 2016. The concept of restitution in South African economic policy documents between 1994 and 2014: An ethical analysis. Unpublished MTh thesis, University of the Western Cape.

Pinker, S. 2011. The better angels of our nature: Why violence has declined. New York: Viking.

Plantinga, C. 1995. Not the way it's supposed to be: A breviary of sin. Grand Rapids: Eerdmans.

Rasmussen, L. 2013. Earth honoring faith: Religious ethics in a new key. Oxford: Oxford University Press.

Sakuba, XS. 2005. The relationship between sin and evil in recent African Christian theologies. MTh mini-thesis, University of the Western Cape.

Serres, M. 2018. The incandescent. London: Bloomsbury.

Smith, JKA. 2017. What stands on the fall? A philosophical exploration. In Smith, JKA and Cavanaugh, WT (eds), Evolution and the fall. Grand Rapids: Eerdmans, 48-64.

Sollereder, B. 2018. God, evolution, and animal suffering: Theodicy without a fall. London: Routledge.

Solomons, DJ. 2018. Reconciliation as a controversial symbol: An analysis of a theological discourse in South Africa between 1968 and 2010. Unpublished PhD dissertation, University of the Western Cape/Vrije Universiteit Amsterdam.

Solomons, DJ. 2019. An unlikely conversation partner: Gustaf Aulén's connection with reconciliation in South Africa, Svensk Teologisk Kvartalskrift 95:93-108.

Southgate, C. 2008. The groaning of creation: God, evolution and the problem of evil. Louisville: Westminster John Knox Press.

Southgate C. 2018a. "Free process" and "only way" arguments. In Rosenberg, S (ed.), Finding ourselves after Darwin. Grand Rapids: Baker Academic, 292-305.

Southgate, C. 201b. Theology in a suffering world: Glory and longing. Cambridge: Cambridge University Press. 
Van den Brink, G. 2011. Should we drop the fall? On taking evil seriously. In Van der Borght, EAJG and Van Geest, P (eds), Strangers and pilgrims. Leiden: Brill, 761777.

Van den Brink, G. 2015. Through Adam's fall. Recontextualizing original sin in evolutionary history. Paper read at a colloquium on Redeeming Sin?, Stellenbosch, August 2015.

Van den Brink, G. 2017. En de aarde bracht voort: Christelijk geloof en evolutie. Utrecht: Boekencentrum.

Van den Brink, G. 2017. What would it mean to characterize human-induced climate change as sin? Paper read at a colloquium on Redeeming Sin?, Denver, November 2015.

Van den Brink, G. 2018. Questions, challenges, and concerns for original sin. In Rosenberg, S (ed.), Finding ourselves after Darwin. Grand Rapids: Baker Academic, 117-129.

Vorster, N. 2015. Created in the image of God: Understanding God's relationship with humanity. Eugene: Pickwick.

Vorster, N. 2016. Reconstructing distorted racial identities in post-Apartheid SouthAfrica. A theological perspective. Paper read at a colloquium on Redeeming Sin?, San Antonio, November 2016.

Williams, RR. 1985. Sin and evil. In Hodgson, PC and King, RH (eds), Christian theology: An introduction to its traditions and tasks. Philadelphia: Fortress, 194221.

Žižek, S. 2011. Living in the end times. London \& New York: Verso. 